\title{
Babánekite, $\mathrm{Cu}_{3}\left(\mathrm{AsO}_{4}\right)_{2} \cdot 8 \mathrm{H}_{2} \mathrm{O}$, from Jáchymov, Czech Republic - a new member of the vivianite group
}

\author{
Jakub PLÁŠIL1*, Pavel ŠKÁCHA2, ${ }^{2}$, Jiří SEJKORA², Radek ŠKODA4, Milan NOVÁK ${ }^{4}$ František \\ VESELOVSKÝ ${ }^{5}$, Jan HLOUŠEK ${ }^{\dagger}$
}

\author{
${ }^{1}$ Institute of Physics, Academy of Sciences of the Czech Republic (ASCR) v.v.i, Na Slovance 2, 18221 Prague 8, Czech Republic; \\ plasil@fzu.cz \\ 2 Department of Mineralogy and Petrology, National Museum, Cirkusová 1740, 19300 Prague 9, Czech Republic \\ ${ }^{3}$ Mining Museum Přibram, Hynka Kličky Place 293, 26101 Přibram VI - Březové Hory, Czech Republic \\ ${ }^{4}$ Department of Geological Sciences, Faculty of Science, Masaryk University, Kotlářská 2, 61137 Brno, Czech Republic \\ ${ }^{5}$ Czech Geological Survey, Geologická 6, 15200 Prague 5, Czech Republic \\ * Jáchymov; deceased on April 27, 2014 \\ * Corresponding author
}

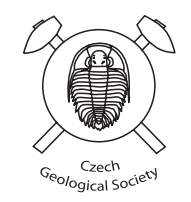

Babánekite, $\mathrm{Cu}_{3}\left(\mathrm{AsO}_{4}\right)_{2} \cdot 8 \mathrm{H}_{2} \mathrm{O}$, a new member of the vivianite group was found in material originating from the Geister vein, Rovnost mine, Jáchymov, Western Bohemia, Czech Republic. It occurs as a supergene alteration mineral in association with members of the lindackerite supergroup (veselovskýite, hloušekite, pradetite and lindackerite), lavendulan, gypsum and an $\mathrm{X}$-ray amorphous $\mathrm{Cu}-\mathrm{Al}-\mathrm{Si}-\mathrm{O}-\mathrm{H}$ phase. Crystals of babánekite are pinkish to peach-colored, elongated, prismatic and up to $2 \mathrm{~mm}$ in length. They exhibit the forms $\{010\},\{100\},\{110\},\{101\}$ and less frequently also $\{001\}$. Crystals are transparent to translucent with a vitreous luster. The mineral has a light pinkish streak. Estimated Mohs hardness is between 1.5 and 2 . The cleavage is perfect on $\{010\}$. The calculated density is $3.192 \mathrm{~g} / \mathrm{cm}^{3}$. Electron-microprobe analysis yielded $\mathrm{CoO} 8.89, \mathrm{NiO} 4.06, \mathrm{CuO} 15.31, \mathrm{ZnO} 10.87, \mathrm{P}_{2} \mathrm{O}_{5} 0.16, \mathrm{As}_{2} \mathrm{O}_{5} 39.79, \mathrm{SO}_{3} 0.13, \mathrm{H}_{2} \mathrm{O} 24.78$ (calc.), total 103.99 wt.\% giving the empirical formula $\left(\mathrm{Cu}_{1.12} \mathrm{Zn}_{0.78} \mathrm{Co}_{0.69} \mathrm{Ni}_{0.32}\right)_{\Sigma 2.91}\left[\left(\mathrm{AsO}_{4}\right)_{2.01}\left(\mathrm{PO}_{4}\right)_{0.01}\left(\mathrm{SO}_{4}\right)_{0.01}\right]_{\Sigma 2.03} \cdot 8 \mathrm{H}_{2} \mathrm{O}$ based on 16 $\mathrm{O}$ apfu. The ideal end-member formula of babánekite is $\mathrm{Cu}_{3}\left(\mathrm{AsO}_{4}\right)_{2} \cdot 8 \mathrm{H}_{2} \mathrm{O}$, which requires $\mathrm{CuO} 38.95, \mathrm{As}_{2} \mathrm{O}_{5} 37.52$, $\mathrm{H}_{2} \mathrm{O} 23.53$, total 100.00 wt.\%. Babánekite is monoclinic, $C 2 / m$, with $a=10.1729(3), b=13.5088(4), c=4.7496(1) \AA$, $\beta=105.399(2)^{\circ}, V=629.28(3) \AA^{3}$ and $Z=2$. The eight strongest X-ray powder diffraction lines are $\left[d_{\mathrm{obs}} \AA(\mathrm{I})(h k l)\right]$ : 7.936(11)(110), 6.743(100)(020), 3.231(14)(13-1), 2.715(11)(041), 2.3331(10)(15-1), 2.0819(5)(350), 1.6862(16)(080) and 1.6107(4)(55-1). The crystal structure of babánekite, refined to $R_{1}=2.18 \%$ for 864 unique observed reflections, confirmed that the atomic arrangement is similar to other members of the vivianite group of minerals. The mineral is named for Ing. František Babánek (1836-1910), Czech mining and geological expert, who worked in the Jáchymov and Př́bram mines.

Keywords: babánekite, new mineral, vivianite group, crystal structure, Jáchymov

Received: 13 September, 2017; accepted: 3 January, 2018; handling editor: F. Laufek

The online version of this article (doi: 10.3190/jgeosci.248) contains supplementary electronic material.

\section{Introduction}

The vivianite group unifies hydrated arsenates and phosphates with the generalized structural formula $\mathrm{Me}_{3}\left(\mathrm{XO}_{4}\right)_{2}\left(\mathrm{H}_{2} \mathrm{O}\right)_{8}$, where $\mathrm{Me}$ designates sites that are occupied by various divalent cations and $X$ the site occupied by $\mathrm{As}^{5+}$ or $\mathrm{P}^{5+}$. To date, six As-dominant members of this group are known: annabergite (Ni), erythrite (Co), hörnesite $(\mathrm{Mg})$, manganohörnesite $(\mathrm{Mn})$, köttigite $(\mathrm{Zn})$ and parasymplesite $(\mathrm{Fe})$. In addition, four P-dominant members have been described: arupite $(\mathrm{Ni})$, barićite $(\mathrm{Mg}, \mathrm{Fe})$, pakhomovskyite $(\mathrm{Co})$ and vivianite $(\mathrm{Fe})$. Broad solid-solutions taking place at the cationic sites have been established especially for As-dominant members.

In this work we report on the new mineral species babánekite, ideally $\mathrm{Cu}_{3}\left(\mathrm{AsO}_{4}\right)_{2} \cdot 8 \mathrm{H}_{2} \mathrm{O}$. It is a $\mathrm{Cu}$ - and
As-dominant member of the vivianite group that was found in the Rovnost mine, Jáchymov, Czech Republic. The new mineral honors the Senior Mining Counselor (“Oberbergrath”) František Babánek (born October 10, 1836, in Kamenný Přívoz near Jílové, Bohemia; died February 25, 1910, in Prague). František Babánek was a Czech mining expert, geologist and mineralogist. During his active service, he worked in Příbram and later in Jáchymov, the two most important mining districts in Bohemia, then a part of the Austro-Hungarian Empire.

The new mineral was approved by the CNMNC IMA under the code IMA 2012-007. The type specimen is deposited in the collections of the Department of Mineralogy and Petrology of the National Museum, Prague, Czech Republic, catalog number: P1P 8/2011. 


\section{Occurrence}

The Jáchymov ore district (Western Bohemia, Krušné hory Mountains, Czech Republic) presents a classic example of Ag-As-Bi-Co-Ni-U hydrothermal vein-type mineralization (Ondruš et al. 2003; Hloušek et al. 2014). The ore-bearing veins cut medium-grade metasedimentary rocks of Cambrian to Ordovician age, which surround a Variscan granitic pluton. The majority of the primary ore minerals were deposited from mesothermal fluids during Variscan mineralizing processes. More than 430 minerals have been described from Jáchymov, including an extremely diverse assemblage of supergene minerals (see Ondruš et al. 1997, 2003; Hloušek et al. 2014 for review).

Babánekite was found in an old ore-stope on the Geister vein at the $3^{\text {rd }}$ Geister level of the Rovnost (former Werner) mine. The particular locality, Geister vein, was opened by old mining workings from the surface down to the level of the Daniel drainage adit, at the $1^{\text {st }}, 3^{\text {rd }}$, $6^{\text {th }}$, Barbora and Daniel levels. This vertical sequence mostly represents a supergene oxidation zone of the vein opened by mining workings, with the very rich zones of the supergene cementation $\mathrm{Ag}-\mathrm{Hg}$ mineralization at the two last mentioned adit levels (Vogl 1854; Škácha et al. 2014).

The old, near-surface workings (from the $1^{\text {st }}$ to the $6^{\text {th }}$ level), originating partly from the $16^{\text {th }}$ century, were reopened during the first half of the $19^{\text {th }}$ century. The main aim was mining for $\mathrm{U}$, used for glass-staining, and later mostly for extraction of radium. The re-opening of the $3^{\text {rd }}$ and $6^{\text {th }}$ Geister levels was well documented by the mining official Josef Florian Vogl, after whom the mineral voglite is named (Haidinger 1853; Ondruš et al. 1997). Vogl $(1856 \mathrm{a}, \mathrm{b})$ described in detail a varied supergene mineral association from the Geister vein constituted by arsenates of the vivianite group and lindackerite su-

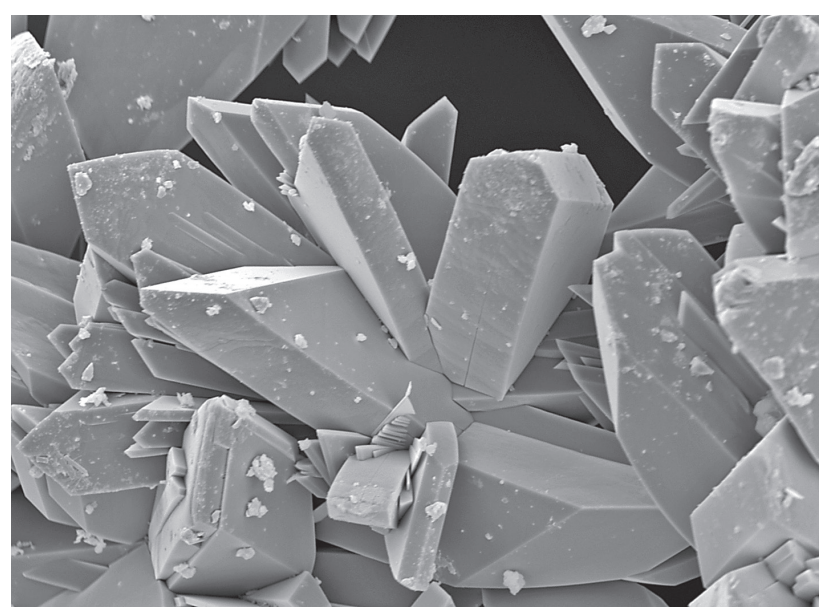

Fig. 1 Detail of babánekite crystals. Secondary electron (SE) image (Hitachi $3700 \mathrm{~N}), 150 \mu \mathrm{m}$ wide. pergroup, as well as supergene uranyl-bearing minerals. The richness of the locality results from the occurrence of both the recently/sub-recently formed minerals connected with the post-mining processes and the supergene minerals formed in-situ in the oxidation zone (association of uranyl arsenates and vanadates; association of $\mathrm{Pb}-\mathrm{Cu}$ supergene minerals and minerals containing $\mathrm{Y}+R E E$ ).

Babánekite was found by one of the authors (PŠ) in an old mining field informally called the "lindackerite stope" by mineral collectors. The name is due to frequent occurrences of the lindackerite-supergroup minerals: lindackerite, veselovskýite (Sejkora et al. 2010), hloušekite (Plášil et al. 2014a), pradetite (unpublished data of the authors) and klajite (Plášil et al. 2014b; Hloušek et al. 2014). These minerals crystallize on the strongly altered ore-body consisting mainly of massive tennantite, galena and chalcopyrite with disseminated uraninite in quartz. Babánekite aggregates grow in cavities and on the surface of ore fragments. In close association with babánekite, members of the lindackerite supergroup, lavendulan, gypsum and $\mathrm{X}$-ray amorphous $\mathrm{Cu}-\mathrm{Al}-\mathrm{Si}-\mathrm{O}-\mathrm{H}$ material were detected, overgrowing relics of the primary minerals partly cemented by supergene mineralization.

\section{Physical and optical properties}

Babánekite forms elongated, prismatic crystals (Fig. 1) up to $1.5 \mathrm{~mm}$ in length, grouped in hemispherical aggregates up to $2 \mathrm{~mm}$ (Fig. 2). Crystals exhibit the forms $\{010\},\{100\},\{110\},\{101\}$ and less frequently also $\{001\}$. Crystals, transparent to translucent, are pinkish to peach in color and have a vitreous luster. Babánekite has a light pink streak. The Mohs hardness is estimated between 1.5 and 2.5 (in analogy with other As-dominant members of the vivianite group). Prismatic crystals show perfect cleavage on $\{010\}$. A density of $3.192 \mathrm{~g} / \mathrm{cm}^{3}$ was calculated using the empirical formula and unit-cell parameters obtained from single-crystal X-ray diffraction. Direct density measurements were not undertaken due to paucity of pure material. Babánekite is non-fluorescent under short- or long-wave UV radiation. Optical properties could not be determined due to zonation of the babánekite crystals available (Fig. 3); the calculated (Gladstone-Dale rule) average $n$ is 1.6615 .

\section{Chemical composition}

The chemical composition of babánekite was determined at Masaryk University in Brno using a Cameca SX100 electron microprobe (WDS mode, $15 \mathrm{kV}, 5 \mathrm{nA}$, and 10 $\mu \mathrm{m}$ beam diameter). The following X-ray lines and standards were selected: $K_{\alpha}$ lines: P (fluorapatite), $\mathrm{Zn}(\mathrm{ZnO})$, $\mathrm{Cu}$ (lammerite), $\mathrm{Co}$ (metallic $\mathrm{Co}$ ), $\mathrm{Ni}(\mathrm{Ni})$ and $\mathrm{S}$ (baryte), 
Fig. 2 Babánekite crystal aggregates consisting of elongated prismatic crystals of dominating $\{010\}$ faces. The bluish material is a PXRD-amorphous $\mathrm{Cu}-\mathrm{Al}-\mathrm{Si}-\mathrm{O}-\mathrm{H}$ phase; metallic minerals are tennantite and chalcopyrite. The width of the image is $3.5 \mathrm{~mm}$.

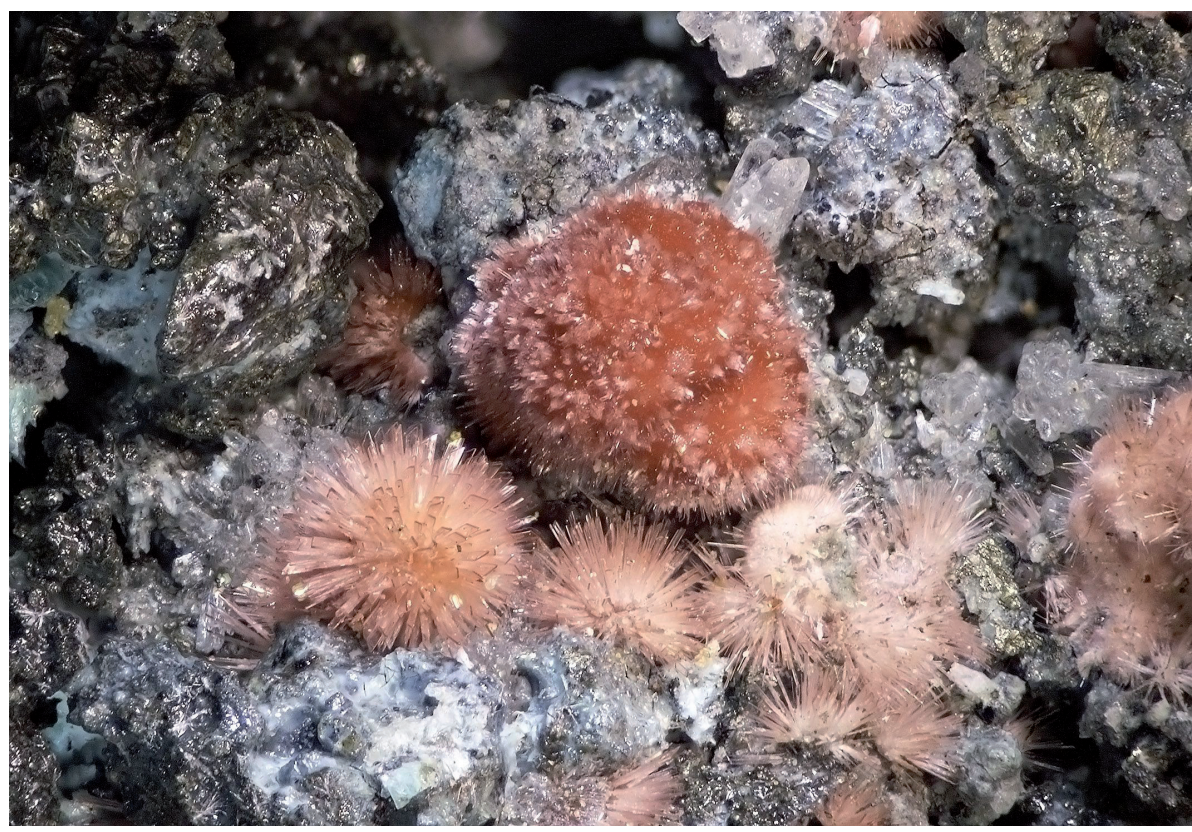

$L_{\alpha}$ line: As (lammerite). Other elements, including $\mathrm{Al}$, $\mathrm{Bi}, \mathrm{Ca}, \mathrm{Cl}, \mathrm{Fe}, \mathrm{K}, \mathrm{Mg}, \mathrm{Mn}, \mathrm{Na}, \mathrm{Pb}, \mathrm{Si}$ and $\mathrm{V}$, were also sought, but not found (the detection limits for these elements are $\sim 0.05-0.10$ wt. $\%$ at the analytical conditions used). Peak counting times were 10-20 s and the counting time for the background their half. The measured intensities were processed for matrix effects using the "PAP" correction routine (Pouchou and Pichoir 1985). The $\mathrm{H}_{2} \mathrm{O}$ content $(8 p f u)$ was calculated based on the stoichiometry obtained from the structure data and by analogy with other vivianite-group minerals.

An aggregate removed from the holotype specimen that was also used for single-crystal and powder X-ray diffraction experiments - is characterized by the presence of slightly $\mathrm{Cu}^{2+}$-dominated crystals $(0.80-1.47 \mathrm{apfu} \mathrm{Cu})$ with sectors/zones enriched by $\mathrm{Zn}^{2+}$ (up to 1.03 ) or $\mathrm{Co}^{2+}$ (up to 0.84 ) or $\mathrm{Ni}^{2+}$ (up to 0.50 apfu) (Fig. 3). In any case, $\mathrm{Cu}^{2+}$ is significantly prevailing in all zones (Fig. 4). The results of electron microprobe analyses of this aggregate (11 point analyses) are summarized in Tab. 1.

Tab. 1 Chemical composition of babánekite from Jáchymov

\begin{tabular}{lccc}
\hline Constituent & Mean of 11 spots (wt. \%) & Range & SD \\
\hline $\mathrm{CoO}$ & 8.89 & $6.48-10.65$ & 0.04 \\
$\mathrm{NiO}$ & 4.06 & $1.20-6.26$ & 0.09 \\
$\mathrm{CuO}$ & 15.31 & $10.72-20.01$ & 3.47 \\
$\mathrm{ZnO}$ & 10.87 & $8.70-14.51$ & 2.20 \\
$\mathrm{P}_{2} \mathrm{O}_{5}$ & 0.16 & $0.10-0.24$ & 0.04 \\
$\mathrm{As}_{2} \mathrm{O}_{5}$ & 39.79 & $39.01-40.58$ & 0.57 \\
$\mathrm{SO}_{3}$ & 0.13 & $0.00-0.37$ & 0.11 \\
$\mathrm{H}_{2} \mathrm{O}^{*}$ & 24.78 & & \\
\hline Total & 103.99 & & \\
\hline
\end{tabular}

* $\mathrm{H}_{2} \mathrm{O}$ content was calculated from stoichiometry $\left(8 \mathrm{H}_{2} \mathrm{O}\right)$ derived from the crystal-structure study

SD - standard deviation
The empirical formula of babánekite (calculated on the basis of $16 \mathrm{O} a p f u)$ is $\left(\mathrm{Cu}_{1.12} \mathrm{Zn}_{0.78} \mathrm{Co}_{0.69} \mathrm{Ni}_{0.32}\right)_{\Sigma 2.91}$ $\left[\left(\mathrm{AsO}_{4}\right)_{2.01}\left(\mathrm{PO}_{4}\right)_{0.01}\left(\mathrm{SO}_{4}\right)_{0.01}\right]_{\Sigma 2.03} \cdot 8 \mathrm{H}_{2} \mathrm{O}$. This formula shows a certain $M e^{2+}$-deficiency and thus it is not fully charge balanced (having 0.26 of negative charge excess). The possible presence of other cations $(\mathrm{Ca}, \mathrm{Pb}, \mathrm{Fe}$, $\mathrm{Mg}, \mathrm{Mn} . .$.$) in concentrations under detection limits of$ the measurement is then the most suitable explanation. The results of crystal structure study do not indicate a presence of $\mathrm{OH}$ groups in this mineral. The ideal endmember formula of babánekite is $\mathrm{Cu}_{3}\left(\mathrm{AsO}_{4}\right)_{2} \cdot 8 \mathrm{H}_{2} \mathrm{O}$, which requires $\mathrm{CuO} 38.95, \mathrm{As}_{2} \mathrm{O}_{5} 37.52$ and $\mathrm{H}_{2} \mathrm{O} 23.53$, total 100.00 wt. $\%$.

Subsequently, we also determined the chemical composition of other crystal aggregates from the holotype sample and also from four additional samples of babánekite from the same locality (Geister vein, Jáchy-

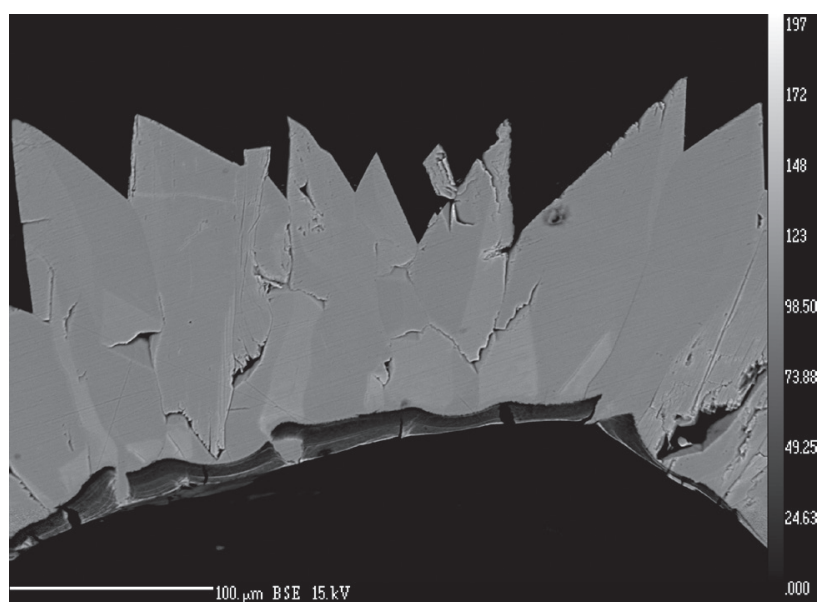

Fig. 3 Zonation of babánekite crystals mainly due to variable Zn contents. Back-scattered electron (BSE) image (Cameca SX100). 


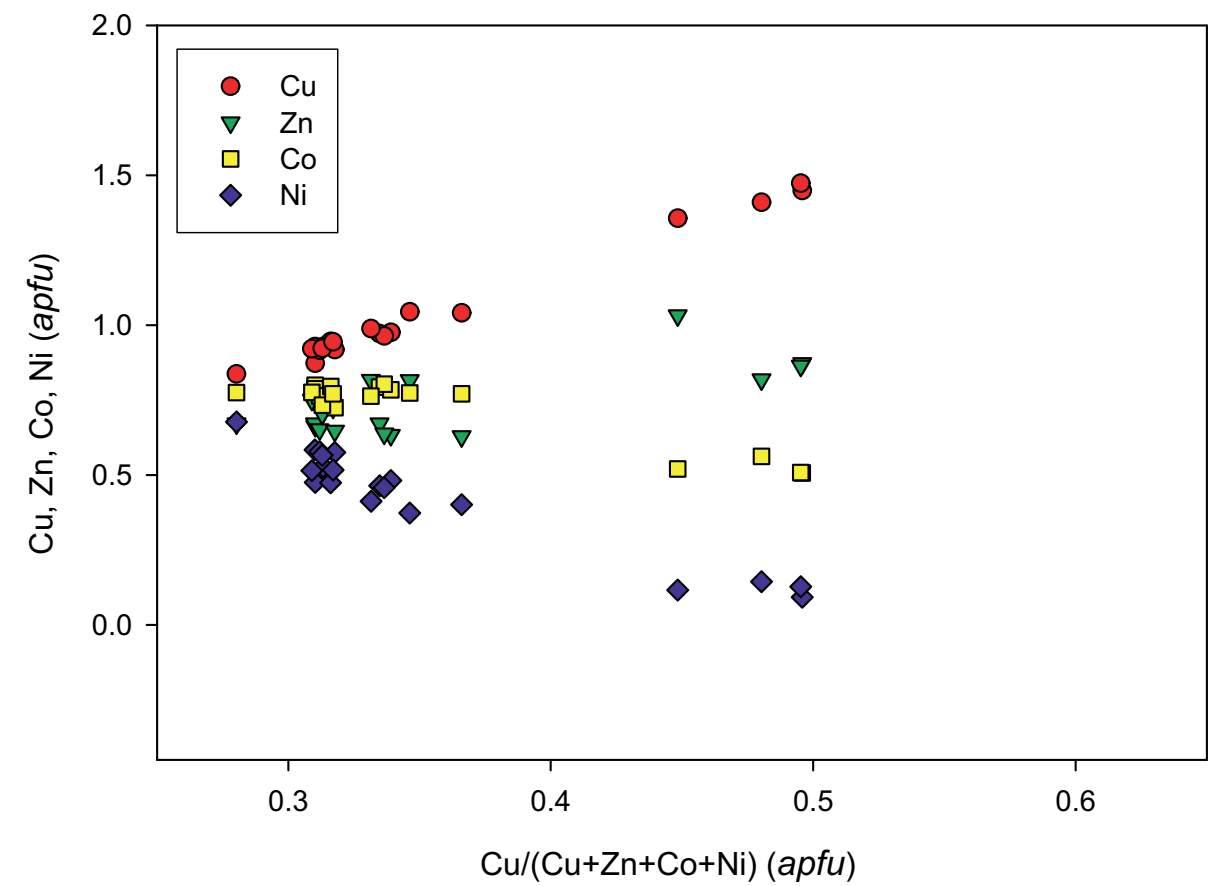

Fig. 4 Plot of $\mathrm{Cu} /(\mathrm{Cu}+\mathrm{Zn}+\mathrm{Co}+\mathrm{Ni})$ vs. individual contents of $\mathrm{Cu}, \mathrm{Zn}, \mathrm{Co}$ and $\mathrm{Ni}$ (all in $a p f u$ ) for the holotype sample of babánekite from Jáchymov. mov), preserved mostly in collections of private mineral collectors. Additional analyses of crystals removed later from the holotype specimen resemble original analyses used for the mineral proposal for CNMNC of IMA (Fig. 4). Apparently, the $\mathrm{Cu}^{2+}$ content correlates negatively both with $\mathrm{Ni}^{2+}$ and $\mathrm{Co}^{2+}$, but not with $\mathrm{Zn}^{2+}$. Other samples of babánekite from Geister vein investigated by EMPA differ significantly particularly in the $\mathrm{Zn}^{2+}$ contents (Fig. 5), which do not exceed $0.14 \mathrm{Zn} a p f u$, along with the even more dominating $\mathrm{Cu}^{2+}$ than for holotype speci- men, reaching up to $1.78 \mathrm{Cu} p f u$. The $\mathrm{Cu}^{2+}$ contents again correlate negatively with $\mathrm{Ni}^{2+}$ (or $\mathrm{Ni}+\mathrm{Co}$ ).

\section{X-ray crystallography and crystal structure}

The X-ray powder diffraction pattern of babánekite (Tab. 2) was obtained from a hand-picked sample utilizing a Bruker D8 Advance diffractometer (National Museum, Prague) with a solid-state 1D LynxEye detector using $\mathrm{Cu} K_{\alpha}$ radiation $(40 \mathrm{kV}, 40 \mathrm{~mA})$. For minimizing the background of the scan, the powder sample was placed onto the surface of a flat silicon wafer from acetone suspension. Powder data were collected in the Bragg-Brentano geometry covering the range $5-70^{\circ} 2 \theta$, with the step size of $0.01^{\circ}$ and counting time of $30 \mathrm{~s}$ per step (total time of experiment about three days). Positions and intensities of diffraction maxima were found and refined using the Pear-

Fig. 5 Plot of $\mathrm{Cu} /(\mathrm{Cu}+\mathrm{Zn}+\mathrm{Co}+\mathrm{Ni})$ vs. individual contents of $\mathrm{Cu}, \mathrm{Zn}, \mathrm{Co}$ and $\mathrm{Ni}$ (all in apfu) for other studied samples of babánekite from the Geister vein, Jáchymov. 
sonVII profile-shape function of the ZDS program package (Ondruš 1995), and the unit-cell parameters were refined by the least-squares algorithm implemented by Burnham (1962).

Refined unit-cell parameters are $a=10.1850(6), b=$ 13.4852(6), $c=4.7484(3) \AA$, $\beta=105.316(5)^{\circ}$, with $V=$ 629.01(6) $\AA^{3}$. Some observed differences (in the range $0.001-$ $0.02 \AA$ ) between parameters obtained from powder and singlecrystal data are probably caused by the slightly different chemical composition of the samples (i.e., zonation; see Figs 3 and 4) by these studies.

A $0.097 \times 0.037 \times 0.034 \mathrm{~mm}$ prismatic crystal of babánekite was selected for single-crystal X-ray diffraction experiment using an Oxford diffraction Gemini single-crystal four-circle diffractometer. Graphitemonochromatized $\mathrm{Mo}_{\alpha}$ radiation $(\lambda=0.71073 \AA)$ from a conventional sealed X-ray tube was collimated with a fiber-optics Mo-Enhance collimator and detected with an Atlas CCD detector. The unit cell of babánekite was refined from 3645 reflections by the least-squares algorithm of the CrysalisPro package giving a monoclinic cell with: $a=$ 10.1742(2), $b=13.5104(3), c=4.7489$ (1) $\AA, \beta=$ $105.416(2)^{\circ}$ and $V=629.29(3) \AA^{3}, Z=2$. From the total of 5722 measured reflections, 1005 were unique, and 864 were classified as unique observed with the criterion $\left[I_{o b s}>3 \sigma(I)\right]$. An empirical (multi-scan) correction for absorption was applied. The summary of data collection, crystallographic data and refinement are listed in Tab. 3.

The crystal structure of babánekite was refined from the single-crystal X-ray data using the known structure model for erythrite (Wildner et al. 1996) and the full-matrix least-squares algorithm of the Jana2006 software (Petříček et al. 2014) based on $F^{2}$. All non-H atoms were refined anisotropically. In the last cycles of the refinement, the occupancies of the $\mathrm{Cu}$ sites were also refined. The refined site occupancy of the $\mathrm{Cu}$ sites, giving a sum of 2.92 atoms per unit cell, suggests that $\mathrm{Cu}$ is mixed at the sites with lighter atoms such as $\mathrm{Co}$ or $\mathrm{Ni}$ and also heavier, as $\mathrm{Zn}$, as well.
Tab. 3 Crystallographic data and refinement details for babánekite

\begin{tabular}{|c|c|}
\hline Structural formula & $\mathrm{Cu}_{3}\left(\mathrm{AsO}_{4}\right)_{2}\left(\mathrm{H}_{2} \mathrm{O}\right)_{8}$ \\
\hline$a, b, c[\AA]$ & $10.1729(3), 13.5088(4), 4.7496(1)$ \\
\hline$\beta\left[^{\circ}\right]$ & $105.399(2)$ \\
\hline$V\left[\AA^{3}\right]$ & $629.28(3)$ \\
\hline Z & 2 \\
\hline$D_{\text {calc }}\left[\mathrm{g} / \mathrm{cm}^{3}\right]$ & 3.206 \\
\hline Space group & $C 2 / m$ \\
\hline Temperature & $298 \mathrm{~K}$ \\
\hline Detector; wavelength & Atlas CCD; $\operatorname{MoK} K_{\alpha}(0.71073 \AA)$ \\
\hline Crystal dimensions $[\mathrm{mm}]$ & $0.097 \times 0.037 \times 0.034$ \\
\hline Collection mode & $\omega$ rotational scans \\
\hline Limiting $\theta$ angles $\left[{ }^{\circ}\right]$ & $3.02-31.13^{\circ}$ \\
\hline Limiting Miller indices & $-13<h<14,-18<k<19,-6<l<6$ \\
\hline No. of reflections & 5722 \\
\hline No. of unique reflections & 1005 \\
\hline No. of observed reflections (criterion) & $864\left[I_{o b s}>3 \sigma(I)\right]$ \\
\hline$R_{\text {int }}$, coverage & $0.033,95 \%$ \\
\hline Absorption correction $\left(\mathrm{mm}^{-1}\right)$, method & 10.20, multi-scan \\
\hline Transmission $(\min /, \max )$ & $0.514 / 0.730$ \\
\hline $\begin{array}{l}F_{000} \\
\text { Refinement by Jana } 2006 \text { on } F^{2}\end{array}$ & 589 \\
\hline Parameters refined, constraints, restraints & $69,4,6$ \\
\hline$R_{1}, w R_{2}(\mathrm{obs})$ & $0.0218,0.0508$ \\
\hline$R_{1}, w R_{2}($ all $)$ & $0.0277,0.0527$ \\
\hline GOF obs/all & $1.47 / 1.40$ \\
\hline$\Delta \rho_{\min }, \Delta \rho_{\max }\left(\mathrm{e} \AA^{-3}\right)$ & $-0.70,0.65$ \\
\hline Weighting scheme, details & $\sigma, w=1 /\left(\sigma^{2}(I)+0.0004 I^{2}\right)$ \\
\hline
\end{tabular}




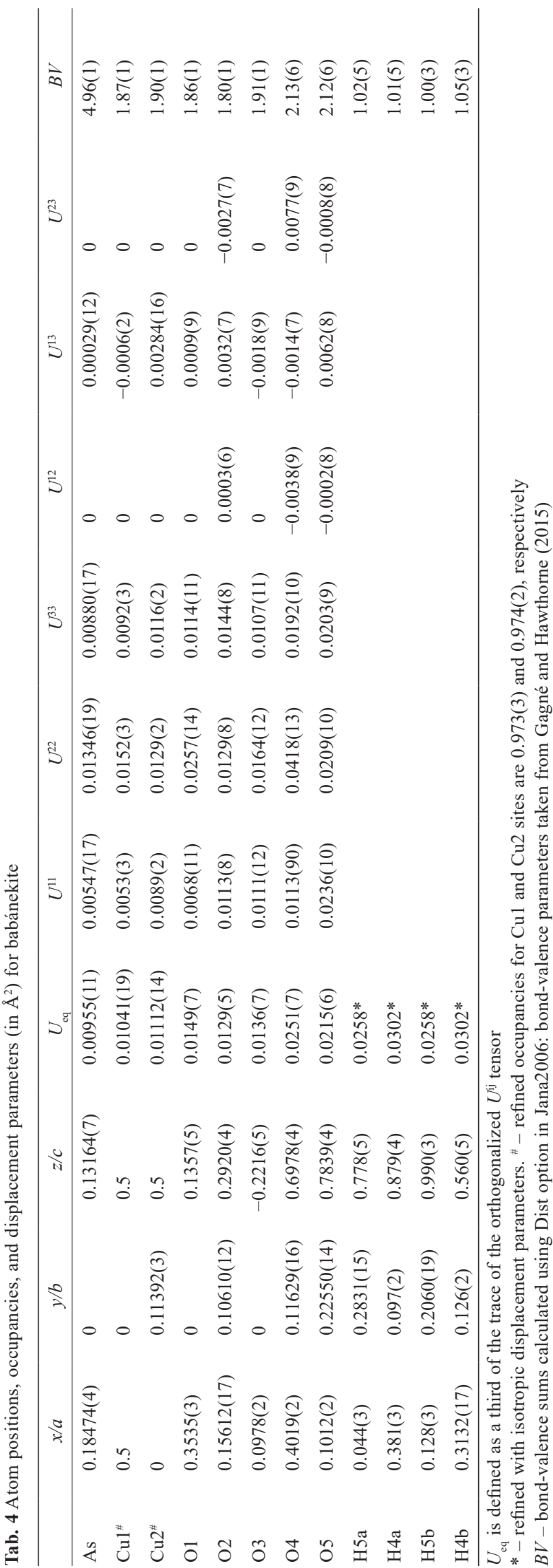

Regarding the fact that $\mathrm{Co}, \mathrm{Ni}, \mathrm{Cu}$ and $\mathrm{Zn}$ (confirmed by the microprobe analysis) have very similar scattering curves, only $\mathrm{Cu}$ was used in the later refinement as a proxy. Both the constrained and unconstrained refinement, which took into account the presence of all atoms mentioned above (and also allowing some degree of the ordering) in the cationic octahedral sites, did not lead either to better or more reasonable results. The constrained refinement fixing the composition, expressed by the empirical formula obtained from the electron-microprobe study, converged to the much worse indices of agreement $(R=0.0290, w R=4.01, \mathrm{GOF}=2.41$ for 864 unique observed reflections) compared to the fit using just the $\mathrm{Cu}$ at the sites. Positions of the hydrogen atoms were localized from difference-Fourier maps. The distance between the $\mathrm{H}$ atom and the corresponding donor $\mathrm{O}$ atom was constrained during the refinement (with a soft constraint of $0.90 \AA$ with a certain weight, that produced $D-\mathrm{H}$ lengths in the range 0.74(3)-0.86(3) $\AA$ ). The displacement parameters of the $\mathrm{H}$ atoms were set to be $1.2 \times U_{\text {iso }}$ of the corresponding donor $\mathrm{O}$ atom. The final cycles converged with $R=0.0218, w R=0.0508$ and $\mathrm{GOF}=1.47$ for 864 observed unique reflections. The correctness of the refined structure model was confirmed by an independent structure solution employing the charge-flipping method (Palatinus and Chapuis 2007). This independent solution obtained differs from the model based on Wildner et al. (1996) only in the order of the estimated errors. Atom positions, displacement parameters and results of the bond valence analysis are listed in Tabs 4 to 5 . Some of the geometrical characteristics (also given in Tab. 4) were calculated using the program Vesta (Momma and Izumi 2008). The bond-valence analysis was carried out following the procedure of Brown (2002). The CIF file, also containing a block with the reflections, is deposited at the Journal's web page www.jgeosci.org.

\subsection{Crystal structure}

The refined structure of babánekite shows characteristic features of the vivianite-type minerals and synthetic compounds, characterized by the general formula $M e^{2+}{ }_{3}\left(\mathrm{XO}_{4}\right)_{2} \cdot 8 \mathrm{H}_{2} \mathrm{O}(\mathrm{Me}=\mathrm{Mg}, \mathrm{Fe}, \mathrm{Co}, \mathrm{Ni}, \mathrm{Zn} ; X=\mathrm{P}, \mathrm{As})$ (Mori and Ito 1950; Cesbron et al. 1977; Hill 1979; Fejdi et al. 1980; Giuseppetti and Tadini 1982; Dormann et al. 1982; Takagi et al. 1986; Riou et al. 1989; Bartl 1989; Wildner et al. 1996; Yakubovich et al. 2001; Capitelli et al. 2007, 2012; Assani et al. 2010; Yoshiasa et al. 2016; Antao and Dhaliwal 2017). Vivianite-type structures consist of $\mathrm{MelO}_{2}\left(\mathrm{H}_{2} \mathrm{O}\right)_{4}$ octahedra and dimers of $\mathrm{Me}_{2} \mathrm{O}_{6}\left(\mathrm{H}_{2} \mathrm{O}\right)_{4}$ octahedra that are linked via $\mathrm{XO}_{4}$ tetrahedra (where $X=$ $\mathrm{P}$, As and probably can be also $\mathrm{V}$ ) and hydrogen bonds to form complex layers parallel to (010). Adjacent layers are linked by hydrogen bonds only (Fig. 6). 

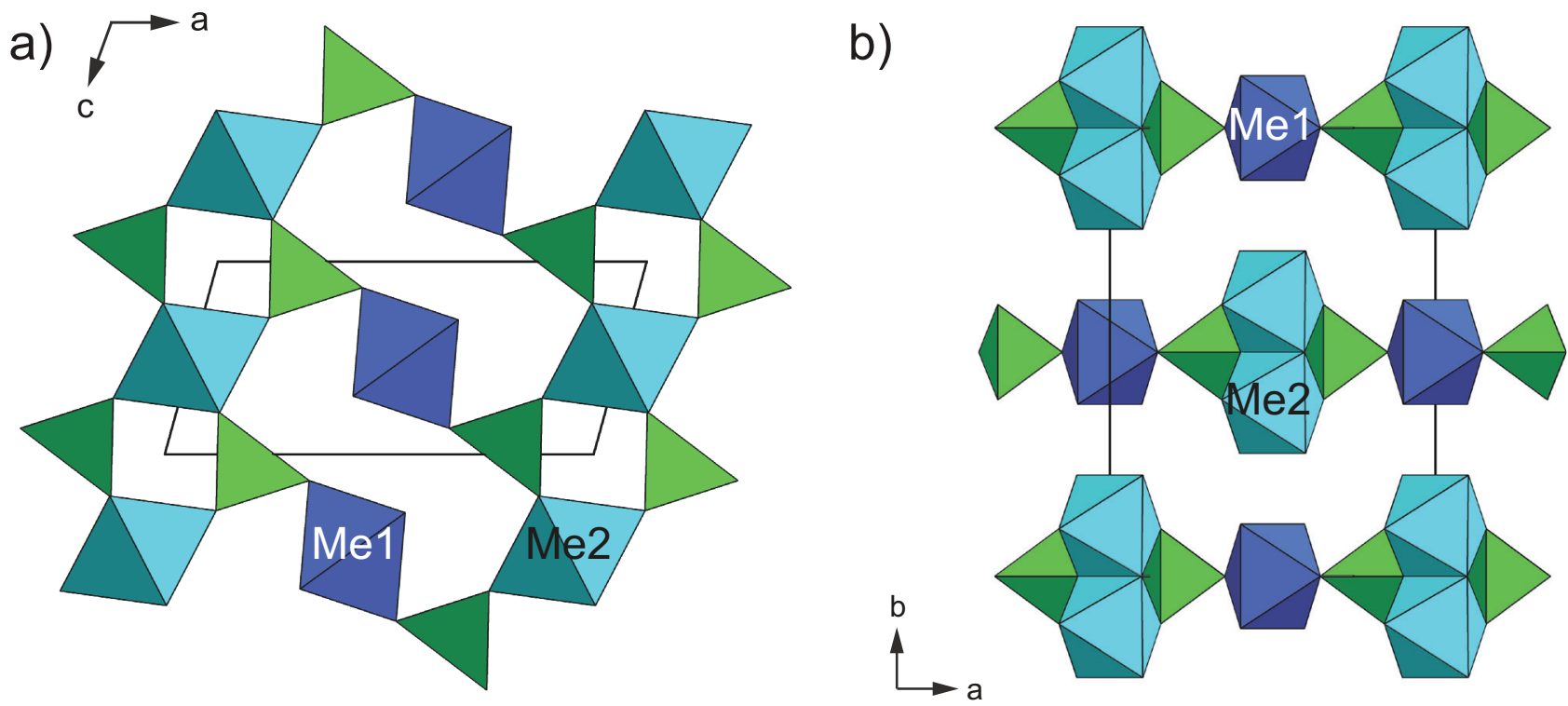

Fig. 6 The crystal structure of babánekite. a - Part of infinite sheet viewed along [010] consisting of vertex-sharing Me1 and Me2 distorted octahedra and $\mathrm{AsO}_{4}$ tetrahedra (in green). $\mathbf{b}$ - The stacking of infinite sheets perpendicular to [010]; adjacent sheets are linked by $\mathrm{H}$-bonds (H atoms and bonds omitted for clarity). Unit-cell edges are outlined in black solid lines.

The $M e^{2+}$ cations, in babánekite dominantly $\mathrm{Cu}^{2+}$, occupy two symmetrically distinct sites with the site-symmetries $2 / m$ and 2 (Wyckoff sites $2 d$ and $4 h$ of the space group $C 2 / m)$. The Cul-centred $(\mathrm{Me} 1)$ polyhedron forms a monomeric entity, which is linked via arsenate group to the dimer of $\mathrm{Cu} 2$-centred ( $\mathrm{Me} 2$ ) polyhedra. The Cu1-centred polyhedron is considerably more irregular (in the terms of "effective coordination number", $\mathrm{ECoN}=5.07$, bond-length distortion index $\Delta=0.05)$ than the Cu2-centred polyhedron $(\mathrm{ECoN}=6.00, \Delta=0.003)$. This is a general feature also observed for other members of the vivianite-group of minerals (e.g., Giuseppetti and Tadini 1982, Yakubovich et al. 2001). It is probably caused due to less-firmly bonded ligands to the $M e 1$ site: only two atoms are $\mathrm{O}^{2-}$ cations, the rest of the ligands represent the $\mathrm{H}_{2} \mathrm{O}$ groups. The bonding in dimers of the $M e 2$-centered polyhedra is much more rigid: only four of the ten ligands belong to the $\mathrm{H}_{2} \mathrm{O}$ groups.

\section{Discussion: the vivianite group of minerals - nomenclature issues}

The present description of babánekite enlarges the family of As-dominant volume (in $\AA^{3}$ ) (xv) $x-1 / 2,-y+1 / 2, z$ members in the vivianite group to seven. In Tab. 6, a general comparison of these members is given based on

Tab. 5 Selected interatomic distances (in $\AA$ ) in the crystal structure of babánekite

\begin{tabular}{|c|c|c|c|}
\hline $\mathrm{Cu} 1-\mathrm{O} 1$ & $1.961(2)$ & $\mathrm{Cu} 2-\mathrm{O} 2$ & $2.084(2)$ \\
\hline $\mathrm{Cu} 1-\mathrm{O} 1^{\text {iv }}$ & $1.961(2)$ & $\mathrm{Cu} 2-\mathrm{O} 2^{\mathrm{vi}}$ & $2.084(2)$ \\
\hline $\mathrm{Cu} 1-\mathrm{O} 4$ & $2.201(2)$ & $\mathrm{Cu} 2-\mathrm{O} 3^{\mathrm{vii}}$ & $2.099(1)$ \\
\hline $\mathrm{Cu} 1-\mathrm{O} 4^{\mathrm{iv}}$ & $2.201(2)$ & $\mathrm{Cu} 2-\mathrm{O}^{\text {viii }}$ & $2.099(1)$ \\
\hline $\mathrm{Cu} 1-\mathrm{O} 4^{\mathrm{v}}$ & $2.201(2)$ & $\mathrm{Cu} 2-\mathrm{O} 5$ & $2.101(2)$ \\
\hline $\mathrm{Cu} 1-\mathrm{O} 4^{\mathrm{i}}$ & $2.201(2)$ & $\mathrm{Cu} 2-\mathrm{O} 5^{\mathrm{vi}}$ & $2.101(2)$ \\
\hline$<\mathrm{Cu} 1-\mathrm{O}>$ & 2.122 & $<\mathrm{Cu} 1-\mathrm{O}>$ & 2.094 \\
\hline $\mathrm{V}_{\mathrm{P}}$ & 12.59 & $\mathrm{~V}_{\mathrm{P}}$ & 12.19 \\
\hline$\sigma^{2}$ & 7.18 & $\sigma^{2}$ & 6.95 \\
\hline$\Delta$ & 0.051 & $\Delta$ & 0.003 \\
\hline \multirow[t]{6}{*}{ ECoN } & 5.067 & $\mathrm{ECoN}$ & 5.998 \\
\hline & As-O1 & $1.712(3)$ & \\
\hline & As- $-\mathrm{O} 2$ & $1.684(2)$ & \\
\hline & $\mathrm{As}-\mathrm{O} 2^{\mathrm{i}}$ & $1.684(2)$ & \\
\hline & As-O3 & $1.676(2)$ & \\
\hline & $<$ As1-O $>$ & 1.690 & \\
\hline \multicolumn{4}{|l|}{ H-bonds } \\
\hline & $D^{\cdots} \mathrm{H}$ & $D-\mathrm{A}$ & $<D-\mathrm{H} \cdots A>$ \\
\hline $\mathrm{O} 4-\mathrm{H} 4 \mathrm{a} \cdots \mathrm{O} 1^{\mathrm{vii}}$ & $0.98(2)$ & $2.753(3)$ & $151(3)$ \\
\hline $\mathrm{O} 4-\mathrm{H} 4 \mathrm{~b} \cdots \mathrm{O} 2$ & $0.973(16)$ & $2.725(2)$ & $164(3)$ \\
\hline $\mathrm{O} 5-\mathrm{H} 5 \mathrm{a} \cdots \mathrm{O} 4^{\mathrm{xv}}$ & $0.97(2)$ & $2.899(3)$ & $167.7(18)$ \\
\hline $\mathrm{O} 5-\mathrm{H} 5 \mathrm{~b} \cdots \mathrm{O} 2^{\mathrm{vii}}$ & $0.982(14)$ & $2.833(3)$ & $151(2)$ \\
\hline
\end{tabular}

$\Delta$, Bond-length distortion after Brown and Shannon (1973); $\sigma^{2}$, bond-angle distortion after Robinson et al. (1971); ECoN, effective coordination number after Hoppe (1979); $\mathrm{V}_{\mathrm{p}}$, polyhedral

Calculations by Vesta (Momma and Izumi 2008)

Symmetry codes: (i) $x,-y, z$; (ii) $x, y, z-1$; (iii) $x, 2 y, z-1$; (iv) $-x+1, y,-z+1$; (v) $-x+1,-y$, $-z+1$; (vi) $-x, y,-z+1$; (vii) $x, y, z+1$; (viii) $-x, y,-z$; (ix) $-x, y,-z-1$; (x) $x+1 / 2,-y+1 / 2, z$; (xi) $-x+1 / 2,-y+1 / 2,-z+1$; (xii) $-x+1 / 2,-y+1 / 2,-z+2$; (xiii) $-x+1, y,-z+2$; (xiv) $-x, y,-z+2$; 


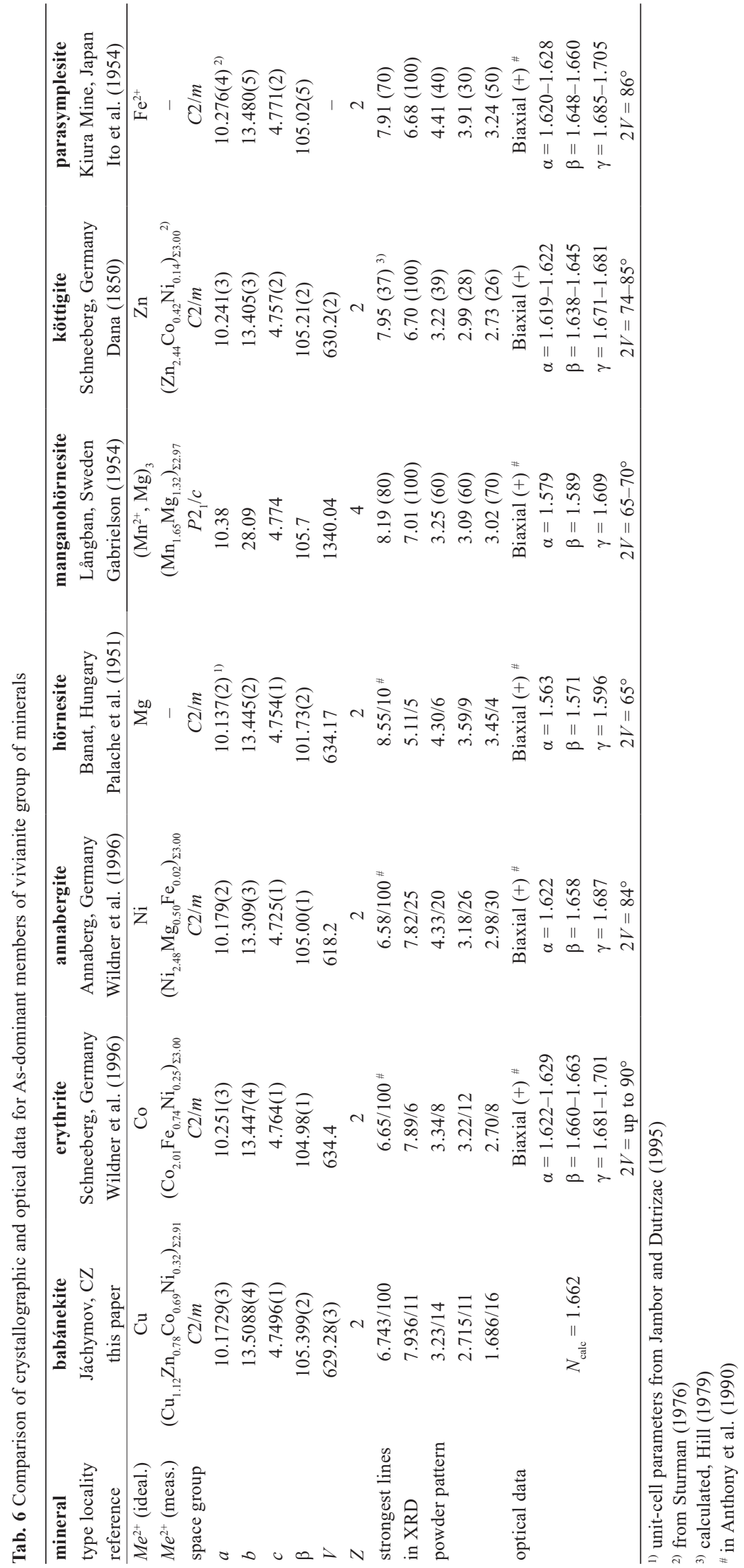

the available data from the literature and the current study. For all these minerals, a broad cationic isomorphy is observed (Jambor and Dutrizac 1995, and others). The $\mathrm{Me}^{2+}$ cations occupy two symmetrically distinct sites in their crystal structure. On the one hand, partial ordering of cations at the $M e 1 / M e 2$ sites was documented by the structure studies for some of the Mg-containing members of the vivianite group (Giuseppetti and Tadini 1982; Rojo et al. 1996; Wildner et al. 1996; Yakubovich et al. 2001). On the other hand, for the members containing $\mathrm{Co}, \mathrm{Zn}$, Ni or $\mathrm{Cu}$ (Hill 1979; Wildner et al. 1996; Capitelli et al. 2007; this study) no such a preference for a certain site was found. Theoretically this can be an artefact, caused by the problematic refinement due to the very similar scattering curves of $\mathrm{Co}, \mathrm{Ni}, \mathrm{Cu}$ and $\mathrm{Zn}$, and therefore impossibility to discern them successfully using X-rays at the same site. Based on current study, the preference of $\mathrm{Cu}^{2+}$ for the $\mathrm{Cu} 1$ site, which is far more irregular than the $\mathrm{Cu} 2$ site (stronger effect of the Jahn-Teller distortion), even though highly probable, also cannot be reliably documented from current X-ray diffraction data. However, the possible preferential entering of the cations was discussed in the study of Antao and Dhaliwal (2017) who documented dominance of the heavier cations $(\mathrm{Co}$, $\mathrm{Ni}, \mathrm{Zn})$ at $\mathrm{Me} 1$ site and lighter cations $\left(\mathrm{Fe}^{2+}\right)$ at the $M e 2$ site. Nowadays, the classification of the particular mineral member of the vivianite group is based on the dominant cation at both sites (i.e. $\Sigma(M e 1+M e 2)$ : Sturman and Mandarino 1976; Giuseppetti and Tadini 1982; Yakubovich et al. 2001).

There have been several descriptions of the increased $\mathrm{Cu}^{2+}$ contents in mineral members of the vivianite group. A significant $\mathrm{Cu}^{2+}$ content in erythrite from Silberberg, near Rattenberg, Tyrol (Austria) was reported by Putz et al. (2012) and from Leogang, Salzburg by Auer (2017). Babánekite has been also found in Germany in the Clara mine (Blaß and Draxler 2015). Recently, we studied other samples from the Geister 
vein, Jáchymov (Czech Republic) and also determined $\mathrm{Cu}$-enriched köttigite (up to $0.99 \mathrm{Cu} p f u$ ), erythrite (up to $0.98 \mathrm{Cu} p f u$ ) and annabergite (up to $0.41 \mathrm{Cu} p f u$ ). The research on these mineral varieties is still ongoing and the results will be the subject of a forthcoming paper.

Acknowledgements. We thank Karla Fejfarová (BIOCEV, ASCR, v.v.i. and Charles University in Prague) and Michal Dušek (Institute of Physics, ASCR, v.v.i.) for help with analytical works. The manuscript benefited from thorough reviews of an anonymous reviewer and Uwe Kolitsch. Handling editor František Laufek is acknowledged for taking care of the manuscript. This research was supported by the project of GAČR No. 17-09161S to J.P. and J.S.

Electronic supplementary material. Supplementary crystallographic data for this paper (including the selected interatomic distances, results of bond-valence analysis and a CIF file) are available online at the Journal website (http://dx.doi.org/10.3190/jgeosci. 248).

\section{References}

ANTAO SM, DhaLIWAL I (2017) Growth oscillatory zoning in erythrite, ideally $\mathrm{Co}_{3}\left(\mathrm{AsO}_{4}\right)_{2} \cdot 8 \mathrm{H}_{2} \mathrm{O}$ : Structural variations in vivianite-group minerals. Minerals $7: 136$, DOI 10.3390/min 7080136

Anthony JW, Bideaux RA, Bladh KW, Nichols MC (1990) Handbook of Mineralogy IV, Arsenates, Phosphates, Vanadates. Mineral Data Publishing, Tucson, Arizona, pp 1-680

Assani A, SaAdi M, El Ammari L (2010) Dicobalt copper bis[orthophosphate(V)] monohydrate, $\mathrm{Co}_{2.39} \mathrm{Cu}_{0.61}\left(\mathrm{PO}_{4}\right)_{2} \cdot \mathrm{H}_{2} \mathrm{O}$. Acta Crystallogr E66: i44

AUER C (2017) 2035) Babanekit vom Nöckelberg bei Leogang, Salzburg. In: WALTER F (ed) Neue Mineralfunde aus Österreich LXVI, Carinthia II, 207/127: 254-255 (in German)

BARTL H (1989) Water of crystallization and its hydrogenbonded crosslinking in vivianite $\mathrm{Fe}_{3}\left(\mathrm{PO}_{4}\right)_{2} \cdot 8 \mathrm{H}_{2} \mathrm{O}$; a neutron diffraction investigation. Fresenius Zeit Anal Chem 333: 401-403

Blass G, Draxler V (2015) Babánekit, ein Erstfund für die Grube Clara im Schwarzwald. Mineralien-Welt 26: 16-19 (in German)

Brown ID (2002) The Chemical Bond in Inorganic Chemistry. The Bond Valence Model. Oxford University Press, Oxford, pp 1-278

Brown ID, SHANnOn RD (1973) Empirical bond-strength bond-length curves for oxides. Acta Crystallogr A29: 266-282

BuRnHAm CW (1962) Lattice constant refinement. Carnegie Institute Washington Yearbook 61: 132-135
Capitelli F, Elaatmani M, Lalaoui MD, Piniella JF (2007) Crystal structure of a vivianite-type mineral: Mg-rich erythrite, $\left.\mathrm{Co}_{2.16} \mathrm{Ni}_{0.24} \mathrm{Mg}_{0.60}\right)\left(\mathrm{AsO}_{4}\right)_{2} \cdot 8 \mathrm{H}_{2} \mathrm{O}$. Z Kristallogr 222: 676-679

Capitelli F, Chita G, Ghiara MR, Rossi M (2012) Crystalchemical investigation of $\mathrm{Fe}_{3}\left(\mathrm{PO}_{4}\right)_{2} \cdot 8 \mathrm{H}_{2} \mathrm{O}$ vivianite minerals. Z Kristallogr 227: 92-101

Cesbron F, Sichere MC, VAchey H (1977) Crystallographic properties and thermal behavior of compounds of the koettigite-parasymplesite series. Bull Soc franç Minéral Cristallog 100: 310-314 (in French)

DANA JD (1850) Köttigite. In: A System of Mineralogy, $3^{\text {rd }}$ Edition. George P. Putnam, New York and London, pp 487

Dormann J-L, Gaspérin M, Poullen J-F (1982) Etude structurale de la sequence d'oxydation de la vivianite $\mathrm{Fe}_{3}\left(\mathrm{PO}_{4}\right)_{2} \cdot 8 \mathrm{H}_{2} \mathrm{O}$. Bull Minéral 105: 147-160

FeJdi P, Poullen J-F, Gaspérin M (1980) Affinement de la structure de la vivianite $\mathrm{Fe}_{3}\left(\mathrm{PO}_{4}\right)_{2} \cdot 8 \mathrm{H}_{2} \mathrm{O}$. Bull Soc franç Minéral Cristallogr 103: 135-138

Gabrielson O (1954) Manganiferous hoernesite and manganese-hoernesite from Långban, Sweden. Arkiv Mineral Geol 1: 333-337

GaGné OC, Hawthorne FC (2015) Comprehensive derivation of bond-valence parameters for ion pairs involving oxygen. Acta Cryst B71: 562-578

Giuseppetti G, TADini C (1982) The crystal structure of cabrerite, $(\mathrm{Ni}, \mathrm{Mg})_{3}\left(\mathrm{AsO}_{4}\right)_{2} \cdot 8 \mathrm{H}_{2} \mathrm{O}$, a variety of annabergite. Bull Soc franç Minéral Cristallogr 105: 333-337

HAIDINGER W (1853) In: Vogl JF Drei neue MineralVorkommen von Joachimsthal. Jb K-Kön Reichsanst 4: $221-223$

HiLl RJ (1979) The crystal structure of köttigite. Amer Miner 64: 376-382

Hloušek J, PlášIl J, SeJkora J, Škácha P (2014) News and new minerals from Jáchymov, Czech Republic (2003-2014). Bull mineral-petrolog odd Nár Muz (Praha) 22: 155-181 (in Czech with English abstract)

Hoppe R (1979) Effective coordination number (ECoN) and mean-fictive ionic radii (Mefir). Z Kristallogr 150: 23-52

Ito T, Minato H, Sakurai K (1954) Parasymplesite, a new mineral polymorphous with symplesite. Proc Japan Acad 30: 318-324

JAMBor JL, DutrizaC JE (1995) Solid solutions in annabergite-erythrite-hörnesite synthetic system. Canad Mineral 33: 1063-1071

Mомма K, IzUmi F (2008) VESTA: a three-dimensional visualization system for electronic and structural analysis. J Appl Cryst 41: 653-658

Mori H, Iто T (1950) The structure of vivianite and symplesite. Acta Cryst 3: 1-6

ONDRUŠ P (1995) ZDS - software for analysis of X-ray powder diffraction patterns. Version 6.01. User's Guide. Prague, 1-120 
Ondruš P, Veselovský F, SkÁla R, Císařová I, HLoušeK J, FrÝda J, VAVŘín I, ČEJKA J, Gabašová A (1997) New naturally occurring phases of secondary origin from Jáchymov (Joachimsthal). J Czech Geol Soc 42: 77-108

Ondruš P, Veselovský F, Gabašová A, Hloušek J, Šrein V, VavŘín I, Skála R, Sejkora J, DrábeK M (2003) Primary minerals of the Jáchymov ore district. J Czech Geol Soc 48: 19-147

Palache C, Berman H, Frondel C (1951) The System of Mineralogy of James Dwight Dana and Edward Salisbury Dana, Yale University 1837-1892, Volume II. Halides, Nitrates, Borates, Carbonates, Sulfates, Phosphates, Arsenates, Tungstates, Molybdates, etc. John Wiley \& Sons, New York, pp 1-755

Palatinus L, Chapuis G (2007) Superflip - a computer program for the solution of crystal structures by charge flipping in arbitrary dimensions. J Appl Cryst 40: 451-456

PetŘíčEK V, DušeK M, PaLATinus L (2014) Crystallographic Computing System JANA2006: general features. Z Krist 229: 345-352

Plášil J, Sejkora J, Škoda R, Novák M, Kasatkin AV, ŠKÁcha P, VeselovskÝ F, FeJfarová K, ONDRUŠ P (2014a) Hloušekite, $(\mathrm{Ni}, \mathrm{Co}) \mathrm{Cu}_{4}\left(\mathrm{AsO}_{4}\right)_{2}\left(\mathrm{AsO}_{3} \mathrm{OH}\right)_{2}\left(\mathrm{H}_{2} \mathrm{O}\right)_{9}$, a new member of the lindackerite supergroup from Jáchymov, Czech Republic. Mineral Mag 78: 1341-1353

PléšIL J, KasatKIN AV, ŠKoda R, ŠKÁCha P (2014b) Klajite, $\mathrm{MnCu}_{4}\left(\mathrm{AsO}_{4}\right)_{2}\left(\mathrm{AsO}_{3} \mathrm{OH}\right)_{2}\left(\mathrm{H}_{2} \mathrm{O}\right)_{10}$, from Jáchymov (Czech Republic): the second world occurrence. Mineral Mag 78: 134-143

PouchOU JL, PichoIR F (1985) “PAP" ( $(\rho \mathrm{Z})$ procedure for improved quantitative microanalysis. In: ARMSTRONG JT (ed) Microbeam Analysis. San Francisco Press, San Francisco, pp 104-106

Putz H, Lechner A, Poeverlein R (2012) Erythrin und Clarait vom Pichlerstollen am Silberberg bei Rattenberg, Nordtirol. Lapis 37: 47-52

Riou A, Cudennec Y, Gérault Y (1989) Cobalt(II) orthophosphate octahydrate. Acta Cryst C45: 1412-1413

Robinson K, GibBs GV, RibBe PH (1971) Quadratic elongation: a quantitative measure of distortion in coordination polyhedra. Science 172: 567-570
Rojo JM, Mesa JL, Pizarro JL, Lezama L, Arriortua Mi, Rojo T (1996) Spectroscopic and magnetic study of the $(\mathrm{Mg}, M)_{3}\left(\mathrm{AsO}_{4}\right)_{2} \cdot 8 \mathrm{H}_{2} \mathrm{O}\left(M=\mathrm{Ni}^{2+}, \mathrm{Co}^{2+}\right)$ arsenates. Mater Res Bull 31: 925-934

Sejkora J, Ondruš P, Novák M (2010) Veselovskýite, triclinic $(\mathrm{Zn}, \mathrm{Cu}, \mathrm{Co}) \mathrm{Cu}_{4}\left(\mathrm{AsO}_{4}\right)_{2}\left(\mathrm{AsO}_{3} \mathrm{OH}\right)_{2} \cdot 9 \mathrm{H}_{2} \mathrm{O}$, a $\mathrm{Zn}$-dominant analogue of lindackerite. Neu Jb Mineral, Abh 187: 83-90

STURMAN BD (1976) New data for köttigite and parasymplesite. Canad Mineral 14: 437-441

Sturman BD, Mandarino JA (1976) Barićite, the magnesium analogue of vivianite, from Yukon Territory, Canada. Canad Mineral 14: 403-406

ŠKácha P, HoRák J, PlášIl J (2014) Minerals and finds of ore shoots on the Geister vein of the western part of the Jáchymov ore district (Czech Republic). Bull mineralpetrolog odd Nár Muz (Praha) 22: 202-214

Takagi S, Mathew M, Brown WE (1986) Crystal structures of bobierrite and synthetic $\mathrm{Mg}_{3}\left(\mathrm{PO}_{4}\right)_{2} \cdot 8 \mathrm{H}_{2} \mathrm{O}$. Amer Miner 71: 1229-1233

Vogl JF (1854) Der neue Silbererz-Anbruch auf dem Geistergange zu Joachimsthal am 1. Oktober 1833. Jb K-Kön Reichsanst 5: 630-640

VoGL JF (1856a) Die sekundären Gebilde der Joachimsthaler Grube. Österr Z Berg- u Hüttenwes 45: 353-355

VoGL JF (1856b) Die sekundären Gebilde der Joachimsthaler Grube. Österr Z Berg u Hüttenwes 46: 361-362

Wildner M, Giester G, Lengauer CL, McCammon CA (1996) Structure and crystal chemistry of vivianite-type compounds: crystal structures of erythrite and annabergite with a Mössbauer study of erythrite. Eur J Mineral 8: $187-192$

YakUbovich OV, Massa W, Liferovich RP, McCammon CA (2001) The crystal structure of barićite, $\left(\mathrm{Mg}_{1.70} \mathrm{Fe}_{1.30}\right)$ $\left(\mathrm{PO}_{4}\right)_{2} \cdot 8 \mathrm{H}_{2} \mathrm{O}$, the magnesium-dominant member of the vivianite group. Canad Mineral 39: 1317-1324

Yoshiasa A, Miyano Y, Isobe H, Sugiyama K, Arima H, NaKatsuka A, Momma K, MiyaWaki R (2016) Structural refinement of köttigite-parasymplesite solid solution: Unique cation site occupancy and chemical bonding with water molecules. J Mineral Petrolog Sci 111: 363-369 